\title{
Evaluation of the in vitro antibacterial activity of the solvent fractions of the leaves of Rhamnus prinoides L'Herit (Rhamnaceae) against pathogenic bacteria
}

Yalew Molla ${ }^{1}$, Teshome Nedi ${ }^{2}$, Getachew Tadesse ${ }^{3}$, Haile Alemayehu ${ }^{4}$ and Workineh Shibeshi ${ }^{2 *}$

\begin{abstract}
Background: Medicinal plants play great roles in the treatment of various infectious diseases. Rhamnus prinoides is one of the medicinal plants used traditionally for treatment of bacterial diseases. The antibacterial activity of the crude extract of the plant had been shown by a previous study, but this study was undertaken to further the claimed medicinal use of the plant by screening its solvent fractions for the said activity so that it could serve as a basis for subsequent studies.

Methods: The solvent fractions of the plant were obtained by successive soxhlet extraction with solvents of increasing polarity, with chloroform and methanol, followed by maceration of the marc of methanol fraction with water. The antibacterial activity of the solvent fractions was evaluated on seven bacterial species using agar well diffusion method at different concentrations (78 mg/well, $39 \mathrm{mg} /$ well and $19.5 \mathrm{mg} /$ well) in the presence of positive and negative controls. The minimum inhibitory concentration of the solvent fractions was determined by micro-broth dilution method using resazurin as indicator.
\end{abstract}

Result: Methanol and chloroform fractions revealed antibacterial activities against the growth of test bacterial strains with varying antibacterial spectrum and the susceptible bacterial species were Staphylococcus aureus, Streptococcus pyogen, Streptococcus pneumoniae and Salmonella typhi. The average minimum inhibitory concentration value of the methanol and chloroform fractions ranged from $8.13 \mathrm{mg} / \mathrm{ml}$ to $32.5 \mathrm{mg} / \mathrm{ml}$ and from $8.13 \mathrm{mg} / \mathrm{ml}$ to $16.25 \mathrm{mg} / \mathrm{ml}$, respectively.

Conclusion: The methanol and chloroform fractions demonstrated significant antibacterial activities against the growth of pathogenic bacteria but the aqueous fraction did not reveal antibacterial activity against any of the test bacteria.

Keywords: Antibacterial activity, Minimum inhibitory concentration, Staphylococcus aureus, Streptococcus pyogen, Streptococcus pneumoniae, Salmonella typhi

Abbreviations: DMSO, Dimethylsulfoxide; ENT, Ear, nose and throat; S. aureus, Staphylococcus aureus; ATCC, American type cell collection; MIC, Minimum inhibitory concentration; MBC, Minimum bactericidal concentration; MHA, Mueller hinton agar; MHB, Mueller hinton broth; S. pyogen species, Staphylococcus pyogen

\footnotetext{
* Correspondence: workineh.shibeshi@aau.edu.et

${ }^{2}$ Department of Pharmacology and Clinical Pharmacy, School of Pharmacy,

Addis Ababa University, P. O. Box, 1176, Addis Ababa, Ethiopia

Full list of author information is available at the end of the article
} 


\section{Background}

Infectious diseases are the continuous major causes of death in the world, with a great impact in developing countries $[1,2]$. The periodically emerging new and old infectious diseases greatly magnify the global burden of infectious diseases [3]. The majorities of emerging infectious events are caused by bacteria which can be associated with evolution of drug resistant strains and overwhelming of the natural host defenses [4, 5].

Therefore, the search of new or alternative mechanisms to effectively treat and prevent infectious diseases, particularly bacterial diseases, have to be encouraged to effectively reduce these global burden. Medicinal plants have been used for treatment of different infectious diseases and thus accepted as alternative approaches. In Africa, $90 \%$ of the population relies on traditional healers to meet their primary healthcare needs [6] which indicate the presence of many medicinal plants with a potential source of new drugs.

Rhamnus prinoides L'Herit (Rhamnaceae) is one of the medicinal plants that have been used traditionally for the treatment of different infectious diseases. Rhamnus prinoides has different ethnomedicinal uses in different countries of Africa. In Kenya, traditionally, the different parts of plant are used in the management of Ear, Nose and Throat (ENT) infections, gonorrhea, malaria and brucellosis [7, 8]. In Ethiopia, the leaves, fruits or roots of Rhamnus prinoides is used to treat tonsillitis [9-13]. In addition, the different parts of the plant have been used in the management of scabies, hepatitis, tinea capitis, 'chiffea' (Eczema), ringworm and dandruff [11, 14-17]. Moreover, the leaf of the plant is used for the management of waterborne and related diseases [18].

The purpose of the study was to evaluate the in vitro antibacterial activities of the crude and solvent fractions of the leaves of Rhamnus prinoides against clinical and standard strains of selected bacterial species, which can in turn provide a clue for the isolation and identification of active principle(s) responsible for the antibacterial activity.

\section{Methods}

\section{Collection and authentication of the plant material}

The leaves of Rhamnus prinoides was collected from the cultivated garden of a family in October 2014, around Debre Markos Town, East Gojjam Zone, Amhara Region, $300 \mathrm{~km}$ away from Addis Ababa, North West Ethiopia and identified by a taxonomist at the National Herbarium, Department of Biology, College of Natural and Computational Sciences, Addis Ababa University, and the specimen (number YM002) was deposited for future references.

\section{Preparation of extracts \\ Crude extraction}

One hundred fifty gram of coarsely powdered leaves was macerated in $80 \%$ methanol for a period of 3 days with occasional shaking using a shaker (Bibby scientific limited stone Staffo Reshire, United Kingdom). The extract was filtered with Whatman No 1 filter paper (Schleicher and Schuell Microscience Gmbh, Germany). The residue was remacerated for the second and third times with fresh solvent. The extracted solution was combined and concentrated by Rota vapor (Buchi Rota-vapor R-200, Switzerland). Then, it was dried in a lyophilizer (Operan, Korea vacuum limited, Korea).

\section{Solvent fractionation}

The solvent fractionation was conducted by using both Soxhlet and maceration techniques. Soxhlet extraction was carried out by sequential extraction of the powdered leaves in solvents of increasing polarity viz. chloroform and methanol as described by a study [19]. The powdered leaf was extracted by chloroform at a temperature not exceeding $40{ }^{\circ} \mathrm{C}$. This extraction process was continued exhaustively until clear solution in the timble was siphoned into the solvent flask. Then, the chloroform fraction was filtered with Whatman No. 1 filter paper and concentrated using rotary evaporator. The concentrated solution was dried in oven at a temperature of $40{ }^{\circ} \mathrm{C}$.

The dried marc of the chloroform fraction was extracted using absolute methanol following the same procedure described for chloroform fraction. Finally, the dried marc of methanol fraction was macerated with distilled water and dried in the lyophilizer to get the aqueous fraction.

The percentage yield of the crude extract, aqueous fraction, methanol fraction, and chloroform fraction were $17.5 \%, 4.32 \%, 8.74 \%$ and $6.21 \%$, respectively. Each dried crude extract and solvent fractions was reconstituted in sterile $20 \%$ DMSO (for crude extract and the methanol fraction), $70 \%$ DMSO (for the chloroform fraction) or sterilized distilled water (for aqueous fraction) to prepare the tested concentrations of the plant material.

\section{Phytochemical screening}

The qualitative phytochemical investigations of the crude extract, and chloroform, methanol and aqueous fractions of leaves of Rhamnus prinoides were carried out using standard tests [20-22]

\section{Inoculum preparation and standardization}

Standard and clinical isolates of different bacterial strains including Escherichia coli (E. coli) (American Type Culture Collection (ATCC) 25922), E. coli (clinical isolate), 
Pseudomonas aeruginosa (P. aeruginosa) (ATCC 27853), P. aeruginosa (Clinical isolate), Staphylococcus aureus (S. aureus) (ATCC 25923), S. aureus (clinical isolate), Shigella flexneri (S. fleneri) (ATCC 12022), S. fleneri (clinical isolates), Streptococcus pneumoniae (S.pneumoniae) (ATCC 49619), S. pneumoniae (clinical isolate), Streptococcus pyogen (S. pyogen) (ATCC 19615), S.pyogen (clinical isolate) and Salmonella typhi (S. typhi) (ATCC 13062) were obtained from Ethiopian Public Health Institution (EPHI). Then, each bacterial strain was inoculated and spread on pre-labeled nutrient agar and $5 \%$ sheep blood agar (for streptococcus species) aseptically in a Safety Cabinet (Bioair instruments, Eurolone ${ }^{\circ}$ Company, Italy) and incubated for $24 \mathrm{~h}$ at $37{ }^{\circ} \mathrm{C}$. The bacterial turbidity of each bacterium was prepared by growth method and standardized by following the guideline of Clinical and Laboratory Standard Institute [23]. The turbidity of the inoculum tube was adjusted visually by either adding bacterial colonies or by adding sterile normal saline solution to that of the already prepared 0.5 McFarland standard.

\section{Antibacterial activity assay Agar well diffusion}

The antibacterial agar well diffusion assay was conducted by following the methods described previously [24]. The standardized bacterial broth culture prepared in section 2.4 were streaked evenly on sterile MHA plates or MHA with $5 \%$ sheep blood (for streptococcus species) with cotton swab. After thirty minutes, on each plate, four equidistant wells were made with a $6 \mathrm{~mm}$ diameter sterilized cork borer. The labeled wells were filled with $100 \mu \mathrm{l}$ of $780 \mathrm{mg} / \mathrm{ml}, 390 \mathrm{mg} / \mathrm{ml}$, and $195 \mathrm{mg} / \mathrm{ml}$ of the crude or each of the solvent fractions making the final concentration of $78 \mathrm{mg} /$ well, $39 \mathrm{mg} /$ well and $19.5 \mathrm{mg} /$ well respectively. In addition, the commercial antibiotic discs of ampicillin $0.01 \mathrm{mg} /$ disc (for streptococcus species), cefoxitin $0.03 \mathrm{mg} / \mathrm{disc}$ (for E. coli and S. aureus species) and ciprofloxacin $0.005 \mathrm{mg} / \mathrm{disc}$ (for other bacterial strains) were used as a positive control. The solvents of the crude and each fraction were used as negative controls. Then, the plates were left undisturbed for about $2 \mathrm{~h}$ at room temperature. After incubation at $37^{\circ} \mathrm{C}$ for $24 \mathrm{~h}$, the zone of inhibition was measured using a ruler. The experiment was performed in three independent tests for each bacterial strains and the mean of zones of inhibition was calculated for each extract.

\section{Determination of the Minimum Inhibitory Concentration (MIC)}

The crude extract and solvent fractions that showed antibacterial activity by agar well diffusion method were subjected to serial resazurin based microtitre dilution technique on 96 well plates (Greiner Bio-One, Germany) as described by previous studies $[25,26]$. The first column of microtiter plate was filled with $100 \mu \mathrm{l}$ stock solution $(390 \mathrm{mg} / \mathrm{ml}$ ) of the crude or each active solvent fraction of test material except the last well in which equal amount of the respective solvent was added. Then, all the wells of microtitre plates were filled with sterilized $100 \mu \mathrm{l}$ of MHB [23] or BHI (for streptococcus species) [27]. Two fold serial dilution of the crude extract or solvent fraction (throughout the row) was carried out until the 10th column. The 11th and 12th column were used as the growth control for labeled bacterium in which the $100 \mu \mathrm{l}$ of the solvents of the extract or that of the solvent fraction was added. Then, $30 \mu \mathrm{l}$ of $0.01 \% \mathrm{w} / \mathrm{v}$ resazurin solution was added and mixed in each well.

Briefly, within $15 \mathrm{~min}$ of standardization to approximately $5 \times 10^{6} \mathrm{CFU} / \mathrm{mL}$ with the respective broth, $20 \mu \mathrm{l}$ of bacterial suspension was added to each well except 7th and 8th row which were reserved as extract color contrast control and sterility control, respectively. Subsequently, the serial dilution procedures gave rise to a final concentration of the plant material ranging from $130 \mathrm{mg} / \mathrm{ml}$ to $0.26 \mathrm{mg} / \mathrm{ml}$.

Finally, after wrapping each plate loosely with parafilm, the plates were incubated at $37{ }^{\circ} \mathrm{C}$ for $24 \mathrm{~h}$. In the experiment, each plate had a set of three controls: (a) a column with all solutions with the exception of the test extract or fraction, (b) a row with all solutions except bacterial suspension and the extract or fraction was used as sterility control, (c) a row with all solutions except the bacterial inoculums was used as color contrast control.

After incubation, any color change observed from purple to pink or colorless was taken as positive for growth of bacteria. The lowest concentration of plant leaf extract at which no color change occurred was recorded as the MIC value. All the experiments were performed in triplicates for each bacterium. The average value was taken for the MIC of test plant material.

\section{Determination of Minimum Bactericidal Concentration (MBC)}

$\mathrm{MBC}$ was determined by a method described in different studies [26]. In this technique, the contents of all wells containing a concentration of test material above the MIC value from each triplicate, in the MIC determination test, was streaked on MHA or MHA supplemented with $5 \%$ sheep blood (for streptococcus species) with wire loop aseptically and incubated at $37{ }^{\circ} \mathrm{C}$ for $24 \mathrm{~h}$. The lowest concentration of the extract which showed no bacterial growth after incubation was observed for each triplicate and noted as the MBC. The average value was taken for the $\mathrm{MBC}$ of test material against each bacterium.

\section{Statistical analysis}

The experimental data are expressed as mean \pm Standard Error of the Mean (SEM). Data are analyzed using the 
Statistical Package for the Social Sciences (SPSS), version 16.0 software. The statistical differences of the mean zone of inhibition of crude extract and solvent fractions for individual bacterium was carried out by employing one way analysis of variance (ANOVA) followed by Tukey Post Hoc Multiple Comparison test at a significance level of $P<0.05$.

\section{Results}

\section{Antibacterial activity}

The growth of test bacterial strains was inhibited by the tested concentrations of the crude extract, the methanol fraction and chloroform fraction of the leaves of Rhamnus prinoides in concentration dependent manner (Tables 1, 2 and 3). However, the aqueous fraction was devoid of an antibacterial activity against any of the test bacterium. Among the test bacteria, the most susceptible bacterium at $78 \mathrm{mg} /$ well of crude extract was standard strains of $S$. aureus followed by clinical isolates of S. aureus and standard strains of $S$. pyogen with a mean zone of inhibition of $22 \mathrm{~mm}, 21.67 \mathrm{~mm}$ and $20.33 \mathrm{~mm}$, respectively. In addition, among the gram negative bacteria, standard strains of $S$. typhi were most susceptible at $78 \mathrm{mg} /$ well of the crude extract with the maximum mean zone of inhibition of $17.67 \mathrm{~mm}$ (Table 1).
Similar to the crude extract, the most susceptible bacterium against methanol fraction was standard strains of $S$. aureus followed by standard strains of $S$. pneumoniae with a mean zone of inhibition of $16.17 \mathrm{~mm}$ and $16 \mathrm{~mm}$, respectively, at $78 \mathrm{mg} /$ well concentration. The zone of inhibition of methanol fraction at $78 \mathrm{mg} /$ well against $S$. typhi was also greater than that of its activity against the other gram negative test bacterial strains (Tables 2 and 3).

The most sensitive bacterium against chloroform fraction at $78 \mathrm{mg} /$ well concentration was standard strains of S. pneumoniae followed by standard strains of S. pyogen with a mean zone of inhibition of $15.67 \mathrm{~mm}$, and $15 \mathrm{~mm}$ (Tables 1, 2 and 3). However, this fraction produced no antibacterial activity coverage against $P$. aeruginosa and $E$. coli regardless of their respective strains. Generally, the antibacterial activities of the chloroform fraction in terms of its zone of inhibition were slightly lower than that of the methanol fraction against each bacterial strain for which it was active, especially at $78 \mathrm{mg} /$ well and $39 \mathrm{mg} /$ well concentrations even though the difference at the corresponding concentration were not statistically significant.

\section{Minimum inhibitory concentration of crude extract and solvent fractions}

As presented in Table 4, for the crude extract, the maximum MIC obtained was $8.13 \mathrm{mg} / \mathrm{ml}$ (against E. coli, $P$. aeruginosa and $S$. pneumoniae species) and the minimum

Table 1 Zone of inhibition (in $\mathrm{mm}$ ) of the different concentrations of crude extract and solvent fractions of the leaves of Rhamnus prinoides against gram positive bacteria

\begin{tabular}{|c|c|c|c|c|c|c|c|}
\hline \multirow[t]{3}{*}{ Category of test } & \multirow[t]{3}{*}{ Concentration } & \multicolumn{6}{|l|}{ Bacteria } \\
\hline & & \multicolumn{2}{|l|}{ S. aureus } & \multicolumn{2}{|l|}{ S. pyogen } & \multicolumn{2}{|l|}{ S. pneumoniae } \\
\hline & & Stand & Clinic & Stand & Clinic & Stand & Clinic \\
\hline \multirow[t]{5}{*}{ Crude } & 19.5 mg/well & $16.67 \pm 0.88^{\mathrm{a} 3 \mathrm{~d} 2}$ & $16.67 \pm 0.33^{\mathrm{a} 3 \mathrm{c} 1 \mathrm{~d} 3}$ & $13.67 \pm 0.88^{\mathrm{a} 3 \mathrm{c} 2 \mathrm{~d} 3}$ & $12.33 \pm 0.33^{\mathrm{a} 3 \mathrm{c} 1 \mathrm{~d} 2}$ & $13.33 \pm 0.33^{\mathrm{a} 3 \mathrm{~d} 2}$ & $11.67 \pm 0.33^{\mathrm{a} 3 \mathrm{c} 2 \mathrm{~d} 3}$ \\
\hline & 39 mg/well & $19.67 \pm 0.88^{\mathrm{a} 3}$ & $19.00 \pm 0.58^{\mathrm{a} 3 \mathrm{~d} 1}$ & $18.33 \pm 0.67^{a 3}$ & $16.33 \pm 0.67^{a 3}$ & $16.00 \pm 1.00^{\mathrm{a} 2}$ & $15.33 \pm 0.33^{\mathrm{a} 3 \mathrm{~d} 2}$ \\
\hline & 78 mg/well & $22.00 \pm 0.58^{\mathrm{a} 2}$ & $21.67 \pm 0.33^{\mathrm{a} 2}$ & $20.33 \pm 0.33^{\mathrm{a} 3}$ & $18.67 \pm 0.33^{\mathrm{a} 3}$ & $19.33 \pm 1.20^{\mathrm{a} 1}$ & $18.00 \pm 0.00^{\mathrm{a} 3}$ \\
\hline & Cef 0.03 mg/disc* & $28.33 \pm 0.58$ & $26.33 \pm 0.67$ & NT & NT & NT & NT \\
\hline & Amp 0.01 mg/disc* & NT & NT & $27.33 \pm 0.67$ & $26.33 \pm 1.20$ & $24.00 \pm 0.58$ & $23.00 \pm 0.58$ \\
\hline \multirow[t]{5}{*}{ Methanol } & 19.5 mg/well & $13.00 \pm 0.58^{\mathrm{a} 3 \mathrm{~d} 2 \mathrm{e} 2}$ & $11.67 \pm 0.33^{\text {a3d } 2 \mathrm{e} 3}$ & $12.67 \pm 0.33^{\mathrm{a} 3 \mathrm{~d} 1}$ & $11.67 \pm 0.33^{\mathrm{a} 3 \mathrm{~d} 2}$ & $12.33 \pm 0.88^{\mathrm{a} 3 \mathrm{~d} 1}$ & $11.33 \pm 0.33^{\mathrm{a} 3 \mathrm{~d} 3}$ \\
\hline & 39 mg/well & $14.33 \pm 0.33^{\mathrm{a} 3 \mathrm{f3}}$ & $13.33 \pm 0.33^{\mathrm{a} 3 \mathrm{f3}}$ & $14.00 \pm 0.58^{\mathrm{a} 3 \mathrm{f} 2}$ & $12.67 \pm 0.33^{\mathrm{a} 3 \mathrm{~d} 1 \mathrm{f} 3}$ & $14.33 \pm 0.33^{\mathrm{a} 3}$ & $13.67 \pm 0.33^{\mathrm{a} 3 \mathrm{~d} 1}$ \\
\hline & 78 mg/well & $16.17 \pm 0.44^{\mathrm{a} 3 \mathrm{~g} 3}$ & $15.33 \pm 0.67^{\mathrm{a} 3 \mathrm{~g} 3}$ & $15.00 \pm 0.58^{\mathrm{a} 3 \mathrm{~g} 3}$ & $15.00 \pm 0.58^{\mathrm{a} 3 \mathrm{~g} 3}$ & $16.00 \pm 0.58^{\mathrm{a} 3}$ & $15.33 \pm 0.33^{\mathrm{a} 3 \mathrm{~g} 2}$ \\
\hline & Cef 0.03 mg/disc* & $27.67 \pm 0.33$ & $26.33 \pm 0.33$ & NT & NT & NT & NT \\
\hline & Amp $0.01 \mathrm{mg} / \mathrm{disc}^{*}$ & NT & NT & $28.00 \pm 0.00$ & $26.33 \pm 0.67$ & $25.00 \pm 0.58$ & $23.67 \pm 0.33$ \\
\hline \multirow[t]{5}{*}{ Chloroform } & 19.5 mg/well & $11.67 \pm 0.33^{\mathrm{a} 3 \mathrm{~d} 1 \mathrm{e} 3}$ & $11.67 \pm 0.33^{\mathrm{a} 3 \mathrm{~d} 1 \mathrm{e} 3}$ & $12.00 \pm 0.58^{a 3 d 2}$ & $10.67 \pm 0.33^{\mathrm{a} 3 \mathrm{~d} 2}$ & $12.00 \pm 0.58^{\mathrm{a} 3 \mathrm{~d} 2}$ & $11.00 \pm 0.00^{\mathrm{a} 3 \mathrm{~d} 2}$ \\
\hline & 39 mg/well & $13.00 \pm 0.58^{\mathrm{a} 3 \mathrm{f3}}$ & $13.33 \pm 0.33^{a 3 f 3}$ & $13.67 \pm 0.33^{a 3 f 3}$ & $12.00 \pm 0.58^{a 3 f 3}$ & $14.00 \pm 0.58^{\mathrm{a} 3}$ & $13.00 \pm 0.58^{\mathrm{a} 3 \mathrm{f} 2}$ \\
\hline & 78 mg/well & $14.33 \pm 0.33^{\mathrm{a} 3 \mathrm{~g} 3}$ & $14.00 \pm 0.58^{\mathrm{a} 3 \mathrm{~g} 3}$ & $15.00 \pm 0.58^{\mathrm{a} 3 \mathrm{~g} 3}$ & $13.67 \pm 0.58^{\mathrm{a} 3 \mathrm{~g} 3}$ & $15.67 \pm 0.33^{\mathrm{a} 3 \mathrm{~g} 1}$ & $15.00 \pm 0.58^{\mathrm{a} 3 \mathrm{~g} 3}$ \\
\hline & Cef $0.03 \mathrm{mg} / \mathrm{disc} \mathrm{c}^{*}$ & $27.00 \pm 0.57$ & $26.33 \pm 0.33$ & NT & NT & NT & NT \\
\hline & Amp $0.01 \mathrm{mg} / \mathrm{disc}^{*}$ & NT & NT & $27.67 \pm 0.33$ & $27.00 \pm 0.58$ & $25.00 \pm 0.58$ & $23.67 \pm 0.33$ \\
\hline
\end{tabular}

Values are expressed as Mean \pm S.E.M $(n=3)$, analysis was performed with One-Way ANOVA followed by Tukey test; ${ }^{a}$ compared to positive control, ${ }^{b}$ to 19.5 mg/well, co $39 \mathrm{mg} /$ well, ${ }^{d}$ to $78 \mathrm{mg} /$ well, ${ }^{e}$ to crude $19.5 \mathrm{mg} /$ well, ${ }^{f}$ to crude $39 \mathrm{mg} /$ well, ${ }^{9}$ to crude $78 \mathrm{mg} /$ well; ${ }^{1} P<0.05,{ }^{2} P<0.01,{ }^{3} P<0.001$. The negative control has shown no antibacterial activity. ${ }^{*}=$ positive controls, Stand = standard (ATCC) strains, Clinic. = clinically isolated strains, NT = not tested, Cef $=$ Cefoxitin, Amp = ampicillin, Cip = Ciprofloxacin 
Table 2 Zone of inhibition (in $\mathrm{mm}$ ) of the different concentrations of crude and solvent fractions of the leaves of Rhamnus prinoides against gram negative bacteria

\begin{tabular}{|c|c|c|c|c|c|}
\hline \multirow[t]{3}{*}{ Category of test } & \multirow[t]{3}{*}{ Concentration } & \multicolumn{4}{|l|}{ Bacteria } \\
\hline & & \multicolumn{2}{|l|}{ S. flexneri } & \multicolumn{2}{|l|}{ E. coli } \\
\hline & & Stand & Clinic & Stand & clinic \\
\hline \multirow[t]{5}{*}{ Crude } & 19.5 mg/well & $12.00 \pm 0.58^{\mathrm{a} 3 \mathrm{~d} 2}$ & $11.67 \pm 0.33^{\text {a3d } 2}$ & $11.67 \pm .88^{\mathrm{a} 3 \mathrm{~d} 1}$ & $11.33 \pm 0.67^{\mathrm{a} 3 \mathrm{~d} 2}$ \\
\hline & 39 mg/well & $14.00 \pm 0.00^{\mathrm{a} 3 \mathrm{~d} 1}$ & $13.67 \pm 0.33^{\mathrm{a} 3 \mathrm{~d} 1}$ & $12.67 \pm 0.33^{\mathrm{a} 3}$ & $12.67 \pm 0.33^{\mathrm{a} 3}$ \\
\hline & 78 mg/well & $17.00 \pm 0.58^{\mathrm{a} 3}$ & $16.00 \pm 0.58^{\mathrm{a} 3}$ & $15.00 \pm 0.00^{\mathrm{a} 3}$ & $14.50 \pm 0.29^{\mathrm{a} 3}$ \\
\hline & Cef 0.03 mg/disc ${ }^{*}$ & NT & NT & $28.33 \pm 0.88$ & $27.00 \pm 0.58$ \\
\hline & Cip 0.005 mg/disc* & $26.33 \pm 0.67$ & $25.00 \pm 0.58$ & NT & NT \\
\hline \multirow[t]{5}{*}{ Methanol } & 19.5 mg/well & $11.00 \pm 0.00^{\mathrm{a} 3 \mathrm{~d} 2}$ & $10.67 \pm 0.67^{\mathrm{a} 3 \mathrm{~d} 2}$ & $10.33 \pm 0.33^{\mathrm{a} 3 \mathrm{~d} 3}$ & $9.00 \pm 0.58^{\mathrm{a} 3 \mathrm{c} 2 \mathrm{~d} 3}$ \\
\hline & 39 mg/well & $13.00 \pm 0.58^{\mathrm{a} 3}$ & $12.67 \pm 0.33^{\mathrm{a} 3}$ & $12.00 \pm 0.58^{\mathrm{a} 3 \mathrm{~d} 1}$ & $11.67 \pm 0.33^{\mathrm{a} 3 \mathrm{~d} 2}$ \\
\hline & 78 mg/well & $15.00 \pm 0.58^{\mathrm{a} 3}$ & $14.67 \pm 0.33^{\mathrm{a} 3}$ & $14.50 \pm 0.29^{\mathrm{a} 3}$ & $14.33 \pm 0.33^{\mathrm{a} 3}$ \\
\hline & Cef 0.03 mg/disc & NT & NT & $27.67 \pm 0.33$ & $26.67 \pm 0.33$ \\
\hline & Cip 0.005 mg/disc* & $27.00 \pm 0.58$ & $26.33 \pm 0.67$ & NT & NT \\
\hline \multirow[t]{4}{*}{ Chloroform } & 19.5 mg/well & $10.00 \pm 0.58^{\mathrm{a} 3 \mathrm{~d} 2}$ & $10.33 \pm 0.33^{\mathrm{a} 3}$ & - & - \\
\hline & 39 mg/well & $11.33 \pm 0.33^{\mathrm{a} 3 \mathrm{f1}}$ & $11.67 \pm 0.67^{\mathrm{a} 3}$ & - & - \\
\hline & 78 mg/well & $13.33 \pm 0.333^{\text {a } 392}$ & $12.33 \pm 0.33^{\mathrm{a} 3 \mathrm{~g} 2}$ & - & - \\
\hline & Cip 0.005 mg/disc* & $25.00 \pm 0.58$ & $24.67 \pm 0.33$ & NT & NT \\
\hline
\end{tabular}

Values are expressed as Mean \pm S.E.M $(n=3)$, analysis was performed with One-Way ANOVA followed by Tukey test ${ }^{a}$ compared positive control, ${ }^{b}$ to 19.5 mg/well, co $39 \mathrm{mg} /$ well, ${ }^{d}$ to $78 \mathrm{mg} /$ well, ${ }^{\text {to }}$ crude $19.5 \mathrm{mg} /$ well, ${ }^{\mathrm{f}}$ to crude $39 \mathrm{mg} /$ well, ${ }^{9}$ to crude $78 \mathrm{mg} /$ well; ${ }^{1} P<0.05,{ }^{2} P<0.01,{ }^{3} P<0.001$. The negative control has shown no antibacterial activity. ${ }^{*}=$ positive controls, Stand = standard (ATCC) strains whereas Clinic. = clinically isolated strains, NT $=$ not tested, Cef $=$ Cefoxitin, Cip = Ciprofloxacin, $-=$ no activitiy

MIC was $2.03 \mathrm{mg} / \mathrm{ml}$ (against staphylococcus species). Moreover, unlike the slight differences between the figures of zone of inhibition of the clinically isolated and standard strains within the same species, the MIC values were equal for the strains of the same species with the exception of $S$. flexneri for which the MIC of the clinical isolate is slightly higher $(5.42 \mathrm{mg} / \mathrm{ml})$ than that of its standard ones $(4.06 \mathrm{mg} / \mathrm{ml})$.

The MIC value for methanol fraction ranged from $32.5 \mathrm{mg} / \mathrm{ml}$ (against $E$. coli species) to $8.13 \mathrm{mg} / \mathrm{ml}$ (against

Table 3 Zone of inhibition (in $\mathrm{mm}$ ) of the different concentrations of crude and solvent fractions of the leaves of Rhamnus prinoides against gram negative bacteria

\begin{tabular}{|c|c|c|c|c|}
\hline \multirow[t]{3}{*}{ Category of test } & \multirow[t]{3}{*}{ Concentration } & \multicolumn{3}{|l|}{ Bacteria } \\
\hline & & \multicolumn{2}{|l|}{ P. aeruginosa } & \multirow{2}{*}{$\begin{array}{l}\text { S. typhi } \\
\text { stand }\end{array}$} \\
\hline & & Stand & Clinic & \\
\hline \multirow[t]{4}{*}{ Crude } & $19.5 \mathrm{mg} /$ well & $11.00 \pm 0.58^{\mathrm{a} 3 \mathrm{c} 1 \mathrm{~d} 2}$ & $10.67 \pm 0.88^{\mathrm{a} 3}$ & $13.33 \pm 0.33^{\mathrm{a} 3 \mathrm{~d} 2}$ \\
\hline & 39 mg/well & $13.33 \pm 0.33^{\mathrm{a} 3}$ & $13.00 \pm 0.58^{\mathrm{a} 3}$ & $14.00 \pm 0.58^{\mathrm{a} 3 \mathrm{~d} 2}$ \\
\hline & 78 mg/well & $14.33 \pm 0.33^{\mathrm{a} 3}$ & $14.00 \pm 0.58^{\mathrm{a} 3}$ & $17.67 \pm 0.67^{\mathrm{a} 3}$ \\
\hline & Cip 0.005 mg/disc* & $25.67 \pm 0.33$ & $24.33 \pm 0.88$ & $30.00 \pm 0.58$ \\
\hline \multirow[t]{4}{*}{ Methanol } & 19.5 mg/well & $10.33 \pm 0.33^{\mathrm{a} 3 \mathrm{~d} 1}$ & $10.33 \pm 0.33^{\mathrm{a} 3 \mathrm{c} 1 \mathrm{~d} 2}$ & $11.00 \pm 0.58^{\mathrm{a3d} 2}$ \\
\hline & 39 mg/well & $12.00 \pm 1.00^{\mathrm{a} 3}$ & $12.33 \pm 0.33^{\mathrm{a} 3}$ & $12.67 \pm 0.88^{\mathrm{a} 3 \mathrm{~d} 1}$ \\
\hline & 78 mg/well & $13.67 \pm 0.33^{\mathrm{a} 3}$ & $13.67 \pm 0.33^{\mathrm{a} 3}$ & $15.67 \pm 0.33^{\mathrm{a} 3}$ \\
\hline & Cip 0.005 mg/disc ${ }^{*}$ & $24.33 \pm 0.33$ & $24.00 \pm 0.58$ & $31.00 \pm 0.58$ \\
\hline \multirow[t]{4}{*}{ Chloroform } & 19.5 mg/well & - & - & $10.33 \pm 0.33^{\mathrm{a3d} 2 \mathrm{e} 1}$ \\
\hline & 39 mg/well & - & - & $11.67 \pm 0.33^{\mathrm{a} 3}$ \\
\hline & 78 mg/well & - & - & $13.00 \pm 0.58^{\mathrm{a3g} g}$ \\
\hline & Cip 0.005 mg/disc* & NT & NT & $30.33 \pm 0.33$ \\
\hline
\end{tabular}

Values are expressed as Mean \pm S.E.M $(n=3)$, analysis was performed with One-Way ANOVA followed by Tukey test; ${ }^{a}$ compared to positive control, ${ }^{b}$ to 19.5 mg/well, cto $39 \mathrm{mg} /$ well, ${ }^{d}$ to $78 \mathrm{mg} /$ well, ${ }^{\text {to }}$ crude $19.5 \mathrm{mg} /$ well, ${ }^{f}$ to crude $39 \mathrm{mg} /$ well, ${ }^{9}$ to crude $78 \mathrm{mg} /$ well; ${ }^{1} P<0.05,{ }^{2} P<0.01,{ }^{3} P<0.001$. The negative control has shown no antibacterial activity ${ }^{*}=$ positive control, Stand $=$ standard (ATCC) strains whereas Clinic = clinically isolated strains, Cip $=$ Ciprofloxacin, $-=$ no activity 
Table 4 The MIC (in mg/ml) of the crude extract and the solvent fractions of the leaves of Rhamnus prinoides against gram positive and gram negative bacteria

\begin{tabular}{|c|c|c|c|c|}
\hline \multirow[t]{3}{*}{ Bacteria } & & \multirow{3}{*}{$\begin{array}{l}\text { Crude extract } \\
\text { MIC }\end{array}$} & \multicolumn{2}{|l|}{ Solvent fractions } \\
\hline & & & Methanol fraction & Chloroform fraction \\
\hline & & & $\mathrm{MIC}$ & MIC \\
\hline \multirow[t]{2}{*}{ S. aureus } & Stand. & $2.03 \pm 0.00$ & $8.13 \pm 0.00$ & $8.13 \pm 0.00$ \\
\hline & Clinc. & $2.03 \pm 0.00$ & $8.13 \pm 0.00$ & $16.25 \pm 0.00$ \\
\hline \multirow[t]{2}{*}{ S. pyogen } & Stand. & $4.06 \pm 0.00$ & $8.13 \pm 0.00$ & $8.13 \pm 0.00$ \\
\hline & Clinc. & $4.06 \pm 0.00$ & $8.13 \pm 0.00$ & $16.25 \pm 0.00$ \\
\hline \multirow[t]{2}{*}{ S. pneumoniae } & Stand. & $8.13 \pm 0.00$ & $16.25 \pm 0.00$ & $16.25 \pm 0.00$ \\
\hline & Clinc. & $8.13 \pm 0.00$ & $16.25 \pm 0.00$ & $16.25 \pm 0.00$ \\
\hline \multirow[t]{2}{*}{ S. flexneri } & Stand. & $4.06 \pm 0.00$ & $16.25 \pm 0.00$ & $16.25 \pm 0.00$ \\
\hline & Clinc. & $5.42 \pm 1.36$ & $16.25 \pm 0.00$ & $16.25 \pm 0.00$ \\
\hline \multirow[t]{2}{*}{ E. coli } & Stand. & $8.13 \pm 0.00$ & $32.50 \pm 0.00$ & - \\
\hline & Clinc. & $8.13 \pm 0.00$ & $32.50 \pm 0.00$ & - \\
\hline \multirow[t]{2}{*}{ P. aeruginosa } & Stand. & $8.13 \pm 0.00$ & $16.25 \pm 0.00$ & - \\
\hline & Clinic & $8.13 \pm 0.00$ & $16.25 \pm 0.00$ & - \\
\hline S. typhi & Stand & $4.06 \pm 0.00$ & $16.25 \pm 0.00$ & $16.25 \pm 0.00$ \\
\hline
\end{tabular}

$\mathrm{MIC}=$ Minimum Inhibitory Concentration, the values are the average of triplicate tests. Stand. $=$ standard $($ ATCC) strains whereas Clinic. $=$ clinically isolated strains

S. aureus and S. pyogen species). The MIC figures of the chloroform fraction ranged from $8.13 \mathrm{mg} / \mathrm{ml}$ to $16.25 \mathrm{mg} /$ $\mathrm{ml}$ in all bacterial species for which it was active. For the same bacterial species tested, the MIC of the two active solvent fractions were equal with the exception of clinically isolated strains of $S$. aureus and $S$. pyogen for which the methanol fraction was more potent than the chloroform fraction.

\section{Minimum bactericidal concentration of crude extract and solvent fractions}

The MBC of the crude extract of the study plant was in the range of $16.25 \mathrm{mg} / \mathrm{ml}$ (against both strains of $S$. pneumoniae) to $2.03 \mathrm{mg} / \mathrm{ml}$ (against standard strains of Staphylococcus species). The corresponding values of the methanol fraction were $65 \mathrm{mg} / \mathrm{ml}$ (against clinical isolate of $E$. coli) and $13.54 \mathrm{mg} / \mathrm{ml}$ (against standard strain of $S$. pyogen). The $\mathrm{MBC}$ values of the chloroform fraction ranged from $32.5 \mathrm{mg} / \mathrm{ml}$ to $16.25 \mathrm{mg} / \mathrm{ml}$ against the growth of the susceptible bacterial species (Table 5). Taken together, the crude extract was more potent and killed the bacteria at lower concentration compared to that of the methanol and chloroform fractions.

\section{Phytochemical constituents of the crude extract and solvent fractions}

According to the qualitative phytochemical screening study, the crude extract of the leaf of Rhamnus prinoides was found to be positive for the presence of all of the tested secondary metabolites except for cardiac glycosides, whereas the methanol fraction was positive for the presence of alkaloids, tannins, flavonoids, saponins, polyphenols and terpenoids. The chloroform fraction was confirmed for the presence of tannins, polyphenols, terpenoids, anthraquinones and flavonoids while the aqueous fraction contained only saponins (Table 6).

\section{Discussion}

The present study was undertaken to determine on which fractions do the constituents of the leaves of Rhamnus prinoides responsible for its antibacterial activity are concentrated. In addition, even though the antibacterial activity of the crude extract of the plant had been studied by a previous work in Gondar, Ethiopia [28], the crude extract was also evaluated in this study to assure its antibacterial activity as there was differences in geographical areas of plant collection, bacterial stains, solvent system and the parts of the plant used for extraction purpose.

According to the present study, the zones of inhibition of the bioactive fractions were lower than that of the crude extract at equal concentrations against the individual strains of test bacteria. The reason for the enhanced antibacterial activity of the crude extract might be due to the synergistic or additive effect of the secondary metabolites that were relatively partitioned in the solvent fractions as it had been extracted by the successive solvents of increasing polarity.

The crude extract and the methanol fraction had similar antibacterial activity profile in terms of antibacterial activity coverage and their activity was higher in the gram positive bacteria than that of the majority of gram negative test bacteria at their comparable concentration. 
Table 5 The MBC (in $\mathrm{mg} / \mathrm{ml}$ ) of the crude extract and the solvent fractions of Rhamnus prinoides against gram positive and gram negative bacteria

\begin{tabular}{|c|c|c|c|c|}
\hline \multirow[t]{3}{*}{ Bacteria } & & \multirow{3}{*}{$\begin{array}{l}\text { Crude extract } \\
\text { MBC }\end{array}$} & \multicolumn{2}{|l|}{ Solvent fractions } \\
\hline & & & \multirow{2}{*}{$\begin{array}{l}\text { Methanol fraction } \\
\text { MBC }\end{array}$} & \multirow{2}{*}{$\begin{array}{l}\text { Chloroform fraction } \\
\text { MBC }\end{array}$} \\
\hline & & & & \\
\hline \multirow[t]{2}{*}{ S. aureus } & Stand. & $2.03 \pm 0.00$ & $16.25 \pm 0.00$ & $16.25 \pm 0.00$ \\
\hline & Clinc. & $4.06 \pm 0.00$ & $16.25 \pm 0.00$ & $16.25 \pm 0.00$ \\
\hline \multirow[t]{2}{*}{ S. pyogen } & Stand. & $4.06 \pm 0.00$ & $13.54 \pm 2.71$ & $16.25 \pm 0.00$ \\
\hline & Clinc. & $4.06 \pm 0.00$ & $16.25 \pm 0.00$ & $16.25 \pm 0.00$ \\
\hline \multirow[t]{2}{*}{ S. pneumoniae } & Stand. & $8.13 \pm 0.00$ & $32.50 \pm 0.00$ & $32.50 \pm 0.00$ \\
\hline & Clinc. & $16.25 \pm 0.00$ & $32.50 \pm 0.00$ & $32.50 \pm 0.00$ \\
\hline \multirow[t]{2}{*}{ S. flexneri } & Stand. & $8.13 \pm 0.00$ & $32.50 \pm 0.00$ & $16.25 \pm 0.00$ \\
\hline & Clinc. & $8.13 \pm 0.00$ & $32.50 \pm 0.00$ & $32.50 \pm 0.00$ \\
\hline \multirow[t]{2}{*}{ E. coli } & Stand. & $8.13 \pm 0.00$ & $32.50 \pm 0.00$ & - \\
\hline & Clinc. & $8.13 \pm 0.00$ & $65.00 \pm 0.00$ & - \\
\hline \multirow[t]{2}{*}{$P$. aeruginosa } & Stand. & $8.13 \pm 0.00$ & $32.50 \pm 0.00$ & - \\
\hline & Clinic. & $8.13 \pm 0.00$ & $32.50 \pm 0.00$ & - \\
\hline S. typhi & Stand & $4.06 \pm 0.00$ & $16.25 \pm 0.00$ & $16.25 \pm 0.00$ \\
\hline
\end{tabular}

$\mathrm{MBC}=$ Minimum Bactericidal Concentration, the values are the average of triplicate tests. Stand $=$ standard $($ ATCC) strains whereas Clinic. $=$ clinically isolated strains

Similarly, the mean zone of inhibition of chloroform fraction at its comparable concentration against gram positive bacteria was also greater than that of gram negative bacteria. Obviously, it is not surprising that gram negative bacteria were less susceptible for the crude and the active solvent fractions of the study plant as they have an outer membrane which precludes the partial penetration of the bioactive phytochemicals unlike that of the gram positive bacteria having less effective permeability barrier [29, 30].

Unlike methanol fraction, the chloroform fraction was not active against the clinical and standard strains of $P$. aeruginosa and $E$. coli. In addition, these species were the least susceptible bacteria for the methanol fraction and crude extract at equal concentrations compared to the other test bacteria. The possible reason for the less

Table 6 Preliminary phytochemical investigation of the crude extract and the solvent fractions of leaves of Rhamnus prinoides using chemical test methods

\begin{tabular}{|c|c|c|c|c|}
\hline \multirow[t]{2}{*}{ Metabolites tested } & \multirow{2}{*}{$\begin{array}{l}\text { Crude } \\
\text { extract }\end{array}$} & \multicolumn{3}{|c|}{ Solvent fractions } \\
\hline & & $\begin{array}{l}\text { Chloroform } \\
\text { fraction }\end{array}$ & $\begin{array}{l}\text { Methanol } \\
\text { fraction }\end{array}$ & $\begin{array}{l}\text { Aqueous } \\
\text { fraction }\end{array}$ \\
\hline Alkaloids & + & - & + & - \\
\hline Saponins & + & - & + & + \\
\hline Tannins & + & + & + & - \\
\hline Anthraquinones & + & + & - & - \\
\hline Polyphenols & + & + & + & - \\
\hline Terpenoids & + & + & + & - \\
\hline Flavonoids & + & + & + & - \\
\hline Cardiac glycosides & - & - & - & - \\
\hline
\end{tabular}

$+=$ present, $-=$ absent susceptible nature of these bacterial species could be due to the differences in the resistance mechanisms to the bioactive compounds detected in each solvent fraction among the test bacteria. For example, $P$. aeruginosa and $E$. cloi have the inherent ability of producing different resistance mechanisms like efflux pump [31], expressing AmpC $\beta$-lactamase [32] or biofilm formation [33] which could hinder the antibacterial activity of the bioactive compounds detected in the chloroform fraction.

Furthermore, the differences in the antibacterial spectrum of the methanol and the chloroform fraction against the test bacteria might be linked to the differences in the composition and/or the concentration of the secondary metabolites in the respective fractions. For instance, unlike the chloroform fraction, the presence of alkaloids and saponins in methanol fraction could directly or indirectly enhance its bacterial growth inhibitory effects on gram negative bacteria including $E$. coli and $P$. aeruginosa which were not responsive to the chloroform fraction [34].

The zones of inhibition of the methanol fraction were slightly higher than that of chloroform fraction against each of susceptible strains for which both were active, at equal concentrations. This may be associated with the less diffusible components of the chloroform fraction on the aqueous surfaces of the agar plate $[35,36]$ and their differences in the composition and concentrations of bioactive secondary metabolites.

Unlike the methanol and chloroform fractions, the aqueous fraction was found to be devoid of antibacterial activities against all the test bacterial strains regardless of the concentrations tested. Such type of result in the 
present study is concordant with other similar study following the same solvent fractionation principles in which the aqueous fraction was not having antibacterial activities [37]. The plausible reason for this phenomenon might be due to the localization of the secondary metabolites of the plant in the chloroform and methanol fractions as the plant had been extracted in sequential solvents of increasing polarity. The localization of bioactive metabolites in the active fractions can be supported by the fact that most of the secondary metabolites of the medicinal plants have aromatic rings and hence could be extracted by the organic solvents used sufficiently before being extracted by water [38], which can further be strengthened by the absence of almost all of the secondary metabolites tested in aqueous fraction.

The antibacterial screening findings in terms of zone of inhibition of the crude and the active solvent fractions of Rhamnus prinoides against the respective susceptible bacteria were inversely proportional to their values of $\mathrm{MIC}$ and MBC, with some exception like for S. pneumoniae, that is, the more susceptible the bacteria to the crude extract or the solvent fraction, the less is its corresponding MIC and MBC values, suggesting the reproducibility and consistency of the experiments. In addition, in almost all findings, the $\mathrm{MBC}$ value was equals to or one dilution factor greater than that of the MIC value for each bacterium in the microbroth dilution tests of crude extract and the active solvent fractions, which might indicate the sensitivity of the dilution method in detecting the minimum bacterial turbidity that indicated the growth of bacteria than that of the visual inspection method in which ambiguity of determining the MIC value is common [39].

However, the MIC values of clinical isolate of $S$. flexneri for the crude extract and that of clinical isolate of $S$. aureus and S. pyogen for the chloroform fraction were greater than the corresponding values of the standard strains of the same species. In addition, the MBC values of clinical isolates of $S$. aureus and $S$. pneumoniae for crude extract; $S$. pyogen and E. coli for methanol fraction; and S. flexneri for chloroform were greater than the corresponding values of the standard strains of the same species. These differences in the potency of the crude extract and the active solvent fractions against the strains of the same bacterial species might be associated to the susceptibility differences between the strains in which the clinical isolates could have a higher chance of developing a resistance mechanism of decreasing the access of the bioactive metabolites to the target sites since they had been isolated from the clinic settings in which resistant strains are common [40].

Groups of phytochemical compounds commonly associated antimicrobial activity in medicinal plants are flavonoids, alkaloids, tannins, triterpenoids, essential oils, saponins, glycosides and phenols [41, 42]. Therefore, the antibacterial activity of the leaves of Rhamnus prinoides might be attributed to either the individual class of these compounds present in the crude and the active solvent fractions or to the synergistic effect that each class of compound exerted to give the observed antibacterial activity findings.

\section{Conclusion}

The present study revealed that the chloroform fraction and the methanol fraction of the leaves of Rhamnus prinoides have antibacterial activities against the growth of the selected pathogenic bacteria with varying antibacterial spectrum. Therefore, this study provides scientific support for the traditional use of the medicinal plant in the treatment of bacterial infections that are probably caused by the susceptible bacteria. Further studies aimed at the isolation and identification of active substance in the crude extract, methanol and chloroform fractions of the leaves of Rhamnus prinoides could disclose compounds with better therapeutic values.

\section{Acknowledgements \\ The authors would like to acknowledge Addis Ababa University, Debre Markos University and a thematic research project on pneumonia, diarrhea and mastitis for sponsoring this study, ALIPB for accessing its laboratory facilities, and EPHI for their cooperation in providing bacterial strains and sheep blood.}

\section{Funding}

This is described in acknowledgement.

Availability of data and materials

The data is available in public library of Addis Ababa University in a form of graduate student thesis.

Authors' contributions

YM designed and conducted all laboratory experiments; analyzed and interpreted experimental results. TN, GT, HA and WS participated in supervision, proposal development and manuscript preparations. All authors read and approved the final manuscript.

\section{Competing interests}

The authors declare that they have no competing interests.

Consent for publication

All coauthors have consented the publication of this manuscript.

Ethics approval and consent to participate

The study was approved by Ethics Review Board of School of Pharmacy in Addis Ababa University but no consent was needed.

\section{Author details}

${ }^{1}$ Department of Pharmacy, College of Health Sciences, Debre Markos University, P. O. Box, 269, Debre Markos, Ethiopia. ${ }^{2}$ Department of Pharmacology and Clinical Pharmacy, School of Pharmacy, Addis Ababa University, P. O. Box, 1176, Addis Ababa, Ethiopia. ${ }^{3}$ Department of Biomedical Sciences, College of Veterinary Medicine and Agriculture, Addis Ababa University, P. O. Box, 1176, Addis Ababa, Ethiopia. ${ }^{4}$ Aklilu Lemma Institute of Pathobiology, Addis Ababa University, P. O. Box, 1176, Addis Ababa, Ethiopia.

Received: 23 March 2016 Accepted: 11 August 2016

Published online: 15 August 2016 


\section{References}

1. Mulder NJ, Akinola RO, Mazandu GK, Rapanoel H. Using biological networks to improve our understanding of infectious diseases. Comput Struct Biotechnol J. 2014;11:1-10

2. WHO:The top 10 causes of death. WHO, Geneva. [Online] available at: http://www.who.int/mediacentre/factsheets/fs310/en/index2.html ,2012; [Accessed 18 Oct 2015].

3. Morens DM, Folkers GK, Fauci AS. The challenge of emerging and re-emerging infectious diseases. Nature. 2004;430:242-9.

4. Jones KE, Patel NG, Levy MA, Storeygard A, Balk D, Gittleman JL, et al. Global trends in emerging infectious diseases. Nature. 2008;451:990-3.

5. Malka R, Shochat E, Rom-Kedar V. Bistability and bacterial infections. PLoS ONE. 2010:5:e10010.

6. Kareru PG, Kenji GM, Gachanja AN, Keriko JM, Mungai G. Traditional medicines among the Embu and Mbeere peoples of Kenya. Afr J Tradit Complement Altern Med. 2007:4:75-86.

7. Muthee JK, Gakuya DW, Mbaria JM, Kareru PG, Mulei CM, Njonge FK Ethnobotanical study of anthelmintic and other medicinal plants traditionally used in Loitoktok district of Kenya. J Ethnopharmacol. 2011;135:15-21.

8. Njoroge GN, Bussmann RW. Traditional management of Ear, Nose and Throat (ENT) diseases in Central Kenya. J Ethnobiol Ethnomed. 2006;2:54

9. Birhanu Z. Traditional use of medicinal plants by the ethnic groups of Gondar Zuria District, North-Western Ethiopia. J Nat Remedies. 2013;13:47-53.

10. Enyew A, Asfaw Z, Kelbessa E, Nagappan R. Ethnobotanical study of traditional medicinal plants in and around Fiche District, Central Ethiopia. Curr Res J Biol Sci. 2014;6:154-67.

11. Gebeyehu G, Asfaw Z, Enyew A, Raja N. Ethnobotanical study of traditional medicinal plants and their conservation status in Mecha Woreda, West Gojjam of Ethiopia. Int J pharm \& H care Res. 2014;02:137-54.

12. Kidane B, van Andel T, van der Maesen LJG, Asfaw Z. Use and management of traditional medicinal plants by Maale and Ari ethnic communities in Southern Ethiopia. J Ethnobiol Ethnomed. 2014;10:46.

13. Megersa M, Asfaw Z, Kelbessa E, Beyene A, Woldeab B. An ethnobotanical study of medicinal plants in Wayu Tuka District, East Welega Zone of Oromia Regional State, West Ethiopia. J Ethnobiol Ethnomed. 2013;9:68.

14. d'Avigdor E, Wohlmuth H, Asfaw Z, Awas T. The current status of knowledge of herbal medicine and medicinal plants in Fiche, Ethiopia. J Ethnobiol Ethnomed. 2014:10:38

15. Mesfin K, Tekle G, Tesfay T. Ethnobotanical study of traditional medicinal plants used by indigenous people of Gemad District, Northern Ethiopia. J Med Plants Stud. 2013;1:32-7.

16. Teklay A, Abera B, Giday M. An ethnobotanical study of medicinal plants used in Kilte Awulaelo District, Tigray Region of Ethiopia. J Ethnobiol Ethnomed. 2013:9:65

17. Teklehaymanot T, Giday M. Ethnobotanical study of medicinal plants used by people in Zegie Peninsula, Northwestern Ethiopia. J Ethnobiol Ethnomed. 2007;3:12

18. Siyum D, Woyessa D. Assessment of bacteriological quality and traditional treatment methods of water-borne diseases among well water users in Jimma Town, South West Ethiopia. ARPN J Ag \& Bio Sci. 2013;8:477-86.

19. Kumar N, Kant R, Sinaga M, Yimame B, Belachew T. Preliminary phytochemical screening and in vitro antibacterial evaluation of the leaf and root extract of Azadirachta indica Plant. Int J Pharm Front. 2012:2:32-41.

20. Aiyelaagbe $\mathrm{O}$, Osamudiamen PM. Phytochemical screening for active compounds in Mangifera indica leaf from Ibadan, Oyo State. Plant Sci Res. 2009;2:11-3

21. Ayoola GA, Coker HA, Adesegun SA, Adepoju-Bello AA, Obaweya K, Ezennia EC, et al. Phytochemical screening and antioxidant activities of some selected medicinal plants used for malaria therapy in Southwestern Nigeria. Trop J Pharm Res. 2008;7:1019-24.

22. Farhan $\mathrm{H}$, Rammal H, Hijazi A, Hamad H, Badran B. Phytochemical screening and extraction of polyphenol from stems and leaves of a Lebanese Euphorbia macrolada schyzoceras Boiss. Ann Biol Res. 2012;3:149-56.

23. CLSI: Methods for dilution antimicrobial susceptibility tests for bacteria that grow aerobically; approved standard, 9th edition, M07-A10 document. CLSI, USA, pp 12-19. [Online] available at: http://shop-clsi.org/ site/Sample/_pdf/MO7A10_sample.pdf [Accessed 12 Nov 2014].

24. Andualem G, Umar S, Getnet F, Tekewe A, Alemayehu H, Kebede N. Antimicrobial and phytochemical screening of methanol extracts of three medicinal plants in Ethiopia. Advan Biol Res. 2014:8:101-6.
25. Gahlaut A, Chhillar AK. Evaluation of antibacterial potential of plant extracts using resazurin based microtiter dilution assay. Int J Pharm Sci. 2013:5:372-6.

26. Rouis Z, Abid N, Koudja S, Yangui T, Elaissi A, Cioni PL, et al. Evaluation of the cytotoxic effect and antibacterial, antifungal, and antiviral activities of Hypericum triquetrifolium Turra essential oils from Tunisia. BMC Complement Altern Med. 2013;13:24

27. Bertanha CS, Utrera SH, Gimenez VMM, Groppo M, Silva MLA, Cunha WR, et al. Antibacterial evaluation of Styrax pohlii and isolated compounds. Braz J Pharm Sci. 2013:49:654-8.

28. Berhanu A. Microbial profile of Tella and the role of gesho (Rhamnus prinoides) as bittering and antimicrobial agent in traditional Tella (Beer) production. Int Food Res J. 2014;21:357-65.

29. Nikaido H, Vaara M. Molecular basis of bacterial outer membrane permeability. Microbiol Rev. 1985;49:1-32.

30. Scherrer R, Gerhardt P. Molecular sieving by the Bacillus megaterium cell. J Bacteriol. 1971;107:718-35.

31. Lyer R, Erwin AL. Direct measurement of efflux in Pseudomonas aeruginosa using an environment-sensitive fluorescent dye. Res Microbiol. 2015;166: 516-24.

32. Strateva T, Yordanov D. Pseudomonas aeruginosa - a phenomenon of bacterial resistance. J Med Microbiol. 2009;58:1133-48.

33. Carmen JC, Nelson JL, Beckstead BL, Runyan CM, Robison RA, Schaalje GB, et al. Ultrasonic-enhanced gentamicin transport through colony biofilms of Pseudomonas aeruginosa and Escherichia coli. J Infect Chemother. 2004;10: 193-9.

34. Maatalah MB, Bouzidi NK, Bellahouel S, Merah B, Fortas Z, Soulimani R, et al. Antimicrobial activity of the alkaloids and saponin extracts of Anabasis articulate. E3 J Biotechnol Pharm Res. 2012;3:54-7.

35. Pauli GF, Case RJ, Inui T, Wang Y, Cho S, Fischer NH, et al. New perspectives on natural products in tuberculosis drug research. Life Sci. 2005;78:485-94.

36. Sanchez JGB, Kouznetsov W. Antimycobacterial susceptibility testing methods for natural products research. Braz J Microbiol. 2010;41:270-7.

37. Abeysinghe PD, Weeraddana CDS. Screening of petroleum ether, chloroform, ethyl acetate, ethanol and water extracts of medicinal plant, Avicennia marina for antibacterial activity against antibiotic resistant bacteria species, Staphylococcus and Proteus. J Pharm Biomed Sci. 2011;11:1-4.

38. Cowan MM. Plant products as antimicrobial agents. Clin Microbiol Rev. 1999;12:564-82

39. Ncube NS, Afolayan AJ, Okoh Al. Assessment techniques of antimicrobial properties of natural compounds of plant origin: current methods and future trends. Afr J Biotechnol. 2008;7:1797-806.

40. Canton R, Horcajadad JP, Oliverb A, Garbajosaa PR, Vilab J. Inappropriate use of antibiotics in hospitals: The complex relationship between antibiotic use and antimicrobial resistance. Enferm Infecc Microbiol Clin. 2013:31:3-11.

41. Neog P, Choudhury S, Bhattacharjee A, Chetia P, Choudhury MD. A review on ethnomedicinal plants and their active secondary metabolites in antibacterial drug discovery research. Pleione. 2013;7:413-23.

42. Wright GD. Bacterial resistance to antibiotics: enzymatic degradation and modification. Adv Drug Deliv Rev. 2005;57:1451-70.

\section{Submit your next manuscript to BioMed Central and we will help you at every step:}

- We accept pre-submission inquiries

- Our selector tool helps you to find the most relevant journal

- We provide round the clock customer support

- Convenient online submission

- Thorough peer review

- Inclusion in PubMed and all major indexing services

- Maximum visibility for your research

Submit your manuscript at www.biomedcentral.com/submit 